\title{
Human Gastrin-Releasing Peptide Gene Maps to Chromosome Band 18q21
}

\author{
Anne-Marie Lebacq-Verheyden, ${ }^{1}$ Virginia Bertness, ${ }^{1}$ Ilan Kirsch, ${ }^{1}$ Gregory F. Hollis, ${ }^{1}$ \\ O. Wesley McBride, ${ }^{2}$ and James Battey ${ }^{1}$
}

${ }^{\prime}$ NCI-Navy Medical Oncology Branch; and ${ }^{2}$ Laboratory of Biochemistry, National Cancer Institute, Naval Hospital-Bethesda, Building 8, Room 5101, Bethesda, Maryland 20814.

Received 12 June 1986-Final 2 September 1986

\begin{abstract}
A complementary DNA clone encoding human pre-pro gastrin-releasing peptide, a 27-amino acid neuropeptide and putative growth factor, was used to determine the chromosomal location of this gene. Southern blot hybridization to genomic DNA isolated from a panel of human-rodent somatic cell hybrids unambiguously maps this gene to human chromosome 18. In situ chromosomal hybridization confirms the hybrid data and further localized the gene to chromosome band 18q21. Karyotypic abnormalities in tumors and inherited disease states which involve chromosome band $18 q 21$ may now be studied for correlated changes in the structure and expression of the human GRP gene.
\end{abstract}

\section{INTRODUCTION}

Gastrin-releasing peptide (GRP), a 27amino acid neuropeptide, is a mammalian homolog of the amphibian tetradecapeptide bombesin (1). The carboxy terminal 14-amino acid residues of mammalian GRP are very similar to amphibian bombesin, particularly the terminal heptapeptide which appears to be the biologically active region of the molecule that is critical for binding to receptors (2). Bombesin/GRP has been detected in mammalian brain (3) and also in peripheral nerve cells of the gut (4), where it is known to stimulate the release of gastrin from $G$ cells in the gastric mucosa in dogs and humans. In addition, bombesin/GRP has been detected in the pulmonary endocrine cells of normal bronchial epithelium (5), as well as in lung carcinoid tumors $(6,7)$ and human small-cell lung cancer (SCLC) $(8,9,10)$.

Under certain circumstances, GRP can stimulate the growth of human SCLC cell lines $(11,12)$, normal human bronchial epithelial cells (13), and mouse Swiss 3T3 cells (14), where its growth-promoting properties appear to be mediated by a cell-surface receptor (15). GRP is both synthesized and secreted by some SCLC cell lines and can also stimulate cell growth, indicating this neuropeptide may function as an autocrine growth factor that contributes to the transformed growth properties of SCLC (12).

cDNA clones encoding GRP have recently been obtained from human pulmonary carcinoid (16) and SCLC cDNA libraries (17). Analysis of these clones revealed a pre-pro GRP translation product consisting of a signal sequence, the predicted 27-amino acid GRP neuropeptide, and a novel GRP-associated peptide representing the carboxy portion of the translational reading frame encoding GRP $(16,17)$. Two types of pre-pro GRP cDNA clones were observed in pulmonary carcinoid tissue, which differ only in the GRP-associated peptide coding region 
(18). In addition to these two forms, a third version of pre-pro GRP cDNA, also differing in the GRP-associated peptide coding region, was observed in SCLC cDNA clones (17). Comparison of the sequence of these cDNA clones with a genomic clone containing the human pre-pro GRP gene shows that the three forms of pre-pro GRP transcripts are synthesized from a single gene into a primary transcript which is alternatively processed at two splice donor and two splice acceptor sites (17). At least four peptide hormones (GRP and the three differing GRP-associated peptides) could be generated from a single human $G R P$ gene by alternative RNA splicing and posttranslational processing.

Naylor et al. (20) localized the human $G R P$ gene to chromosome 18 using restriction fragment mapping to genomic DNA from somatic cell hybrids. In this paper, we corroborate this observation by localizing the human pre-pro GRP gene to chromosome 18 by analyzing a panel of 48 rodent-human somatic cell hybrid lines in genomic DNA blotting experiments. In situ chromosomal hybridization confirms localization to chromosome 18 , and further maps the GRP gene to $18 \mathrm{q} 21$.

\section{MATERIALS AND METHODS}

Hybrid Cell Lines. A panel of somatic cell hybrid cell lines was generated by polyethylene glycol fusion of human fibroblast cell lines and either mouse or hamster fibroblast cell lines. The human chromosomes present in each hybrid cell line were determined from analysis of isoenzyme markers previously assigned to each human chromosome (19).

DNA Isolation, Restriction Endonuclease Digestion, and Southern Blotting Hybridization. Genomic DNA samples were prepared from cell lines according to the procedure of Polsky et al. (21). Restriction enzyme digestions were carried out using BamHI (mouse human hybrids) and HindIII (hamster human hybrids) as recommended by the supplier. Digested DNA samples were size fractionated on $0.7 \%$ agarose gels and transferred to nylon membranes. Hybridization was performed in $40 \%$ formamide, $0.75 \mathrm{M}$ $\mathrm{NaCl}, 0.075 \mathrm{M}$ Na citrate, $20 \mathrm{mM}$ Tris, $\mathrm{pH}$ $7.5,20 \mu \mathrm{g} / \mathrm{ml}$ herring sperm DNA, $1 \times$ Denhardt's, and $10 \%$ dextran sulfate, for $16 \mathrm{~h}$ at $42^{\circ} \mathrm{C}$. The probe was a $0.9-\mathrm{kb}$ near-full-length GRP cDNA fragment prepared from a pBR322 subclone (17) and labeled by nick translation to a specific activity of about $2 \times$ $10^{8} \mathrm{cpm}{ }^{32} \mathrm{P} / \mu \mathrm{g}$. Blots were washed at room temperature in $2 \times \mathrm{SSC}, 0.1 \% \mathrm{SDS}$, and finally in $0.1 \times \mathrm{SSC}, 0.1 \%$ SDS at $55^{\circ} \mathrm{C}$. The washed blots were exposed to Kodak XAR-5 film for three to seven days at $-70^{\circ} \mathrm{C}$ using Dupont Cronex intensifying screens.

In Situ Hybridization to Chromosomes. A pBR322-derived plasmid containing a $0.9-\mathrm{kb}$ GRP cDNA fragment cloned into the EcoRI site was nick-translated with $\left[{ }^{3} \mathrm{H}\right] \mathrm{dNTPs}$ to a specific activity $>1 \times 10^{7}$ $\mathrm{cpm} / \mu \mathrm{g}$ and used for in situ hybridizations. Conditions for hybridization, washing, and autoradiography of chromosome spreads are essentially those of Harper and Saunders (22), as modified by Kirsch et al. (23), with additional modifications at the time of probe application to the slides as described by Zabel et al. (24).

\section{RESULTS}

Previous genomic blotting experiments showed that the human GRP cDNA probe hybridizes to three HindIII fragments [11.0 $\mathrm{kb}$ (weakly), $4.6 \mathrm{~kb}$, and $2.9 \mathrm{~kb}(17)]$ and to three BamHI fragments $[14.5 \mathrm{~kb}, 11.0 \mathrm{~kb}$, and $2.7 \mathrm{~kb}$ (Lebacq-Verheyden, unpublished)] in human genomic DNA. Preliminary cross-species Southern blotting experiments using mouse DNA showed two hybridizing BamHI fragments $(8.3 \mathrm{~kb}$ and $6.0 \mathrm{~kb})$. Similar experiments performed with hamster genomic DNA identified two HindIII fragments $(4.2 \mathrm{~kb}$ and $1.0 \mathrm{~kb})$ hybridizing to the human GRP cDNA probe. Thus, species- 
(A) $\mathrm{Ha} A \mathrm{~B} C \mathrm{D} E \mathrm{~F}$ G I J K L M Hu
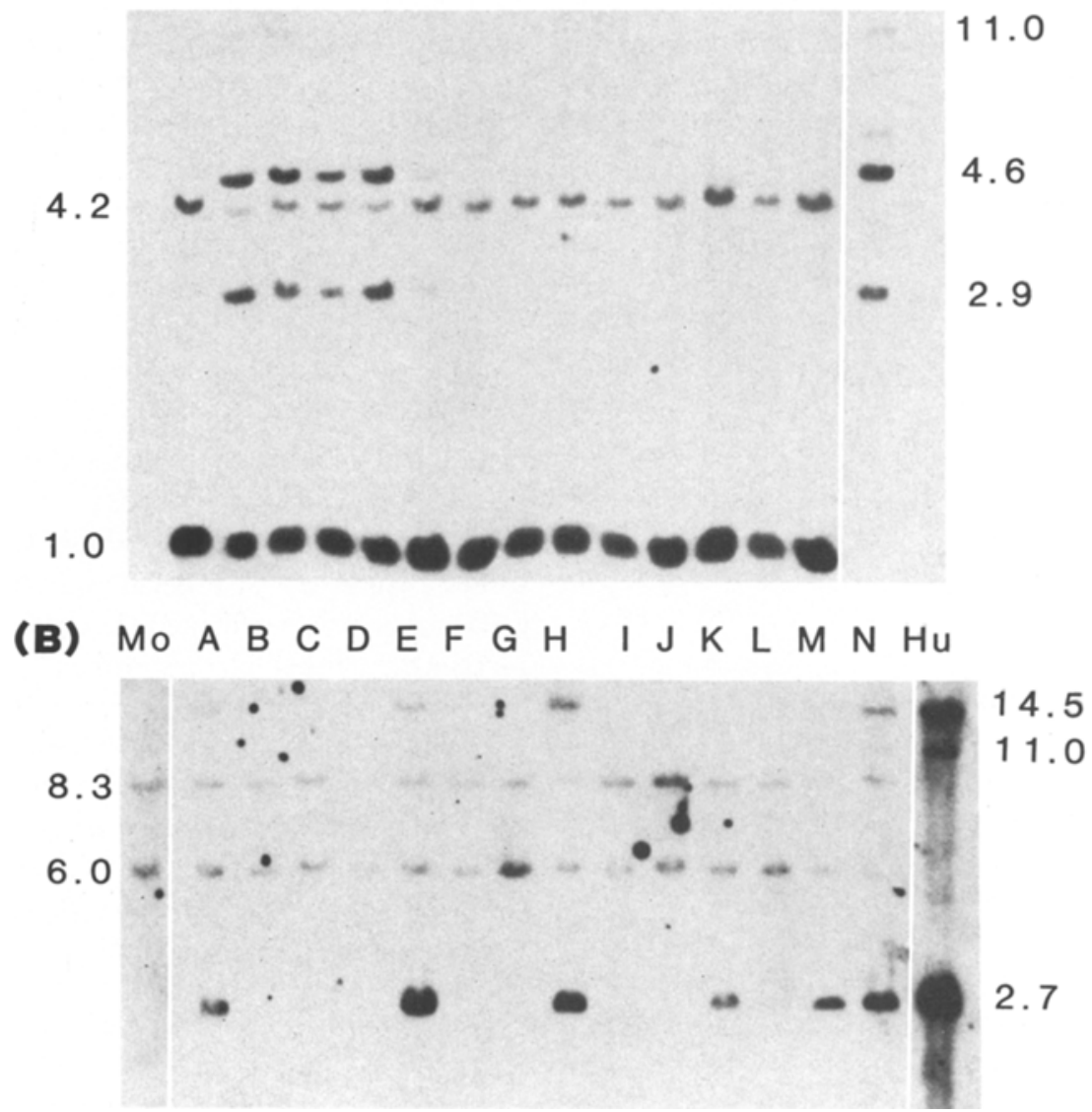

Fig. 1. Southern blots of rodent--human somatic cell hybrid genomic DNA using a human GRP cDNA probe. (A) Genomic DNA from 13 representative hamster-human hybrid cell lines is digested with HindIII and blotted. The human GRP probe reveals the presence (A-E) or absence $(\mathbf{F}-\mathbf{M})$ of human GRP sequences. Control lanes indicate the positions of hamster (Ha; 4.2 and $1.0 \mathrm{~kb})$ and human $(\mathrm{Hu} ; 11.0,4.6$, and $2.9 \mathrm{~kb}) \mathrm{GRP}$ genomic HindIII fragments. Molecular weight markers are lambda digested with HindIII. (B) Genomic DNA from 14 representative mousehuman hybrids is digested with BamHI and blotted. Control lanes indicate the positions of mouse (Mo; $8.3 \mathrm{and} 6.0 \mathrm{~kb})$ and human $(\mathrm{Hu} ; 14.5,11.0$ and $2.7 \mathrm{~kb})$ genomic DNA fragments hybridizing to the human GRP cDNA probe. The presence $(\mathrm{A}, \mathrm{E}, \mathrm{H}, \mathrm{K}, \mathrm{M}, \mathrm{N}$ ) or absence $(\mathrm{B}, \mathrm{C}, \mathrm{D}, \mathrm{F}, \mathrm{G}, \mathrm{I}, \mathrm{J}, \mathrm{L})$ of human GRP sequences in these hybrids is unambiguously determined.

specific fragments homologous to the GRP probe can be readily identified on a HindIII digest of hamster-human hybrid cell genomic DNA, and a BamHI digest of mouse-human hybrid cell DNA. A representative autoradiogram showing HindIII-digested genomic DNA from 13 hamster-human hybrids (A$\mathrm{M}$ ) is shown in Fig. 1 (top). Hybrids A-E clearly contain the human $G R P$ gene, while F-M do not. Similarly, Fig. 1 (bottom) shows
BamHI digests of 14 representative mousehuman hybrid genomic DNAs. In this case A, $\mathrm{E}, \mathrm{H}, \mathrm{K}, \mathrm{M}$, and $\mathrm{N}$ all show human $G R P$ gene fragments, while the others do not.

This analysis was extended to include 48 total rodent-human hybrid cell lines, and the number of cell lines discordant for each human chromosome and the human GRP fragments was determined (Table 1). The discordance is high between all human chro- 
Table 1. Number of Somatic Cell Hybrid Lines

Showing Discordance between Each Human Chromosome and Human GRP Genomic Fragments

\begin{tabular}{cc}
\hline Chromosome & Discordance \\
\hline $1 \mathrm{p}$ & $24 / 48$ \\
$1 \mathrm{q}$ & $22 / 48$ \\
$2 \mathrm{p}$ & $25 / 48$ \\
$2 \mathrm{q}$ & $22 / 48$ \\
3 & $22 / 48$ \\
4 & $26 / 48$ \\
5 & $24 / 48$ \\
$6 \mathrm{p}$ & $26 / 48$ \\
$6 \mathrm{q}$ & $20 / 48$ \\
7 & $22 / 48$ \\
8 & $19 / 48$ \\
9 & $23 / 48$ \\
10 & $28 / 48$ \\
$11 \mathrm{p}$ & $19 / 48$ \\
$11 \mathrm{q}$ & $21 / 48$ \\
$12 \mathrm{p}$ & $22 / 48$ \\
$12 \mathrm{q}$ & $20 / 48$ \\
13 & $15 / 48$ \\
14 & $14 / 48$ \\
15 & $22 / 48$ \\
$16 \mathrm{p}$ & $19 / 48$ \\
$16 \mathrm{q}$ & $14 / 48$ \\
17 & $18 / 48$ \\
$18 *$ & $2 / 48 *$ \\
19 & $24 / 48$ \\
20 & $23 / 48$ \\
21 & $20 / 48$ \\
22 & $27 / 48$ \\
$\mathrm{X}$ & $14 / 48$ \\
\hline & \\
\hline
\end{tabular}

mosomes ( $>14 / 48)$ and human GRP, except chromosome $18(2 / 48)$. In fact, the two hybrid cell lines that appear to show segregation discordance between chromosome 18 and human GRP can be reconciled, and the results provide a basis for regional localization of GRP on this chromosome. Both lines are scored as discordant because they show human GRP but are negative for the isoenzyme marker on chromosome 18 (peptidase A). The peptidase A gene $(P E P-A)$ is located at $18 \mathrm{q} 23$ (near the telomere on the $\mathrm{q}$ arm) (25), while another human gene, $B C L-2$, has been localized at $18 \mathrm{q} 21(26,27)$. Two other sequences present on chromosome 18 are a 1-kb EcoRI fragment (Mt-1 kb) hybridizing with metallothionein probes and a previously described processed $\lambda$ immunoglobulin pseudogene $(\psi \lambda-I)$ (McBride, unpublished re- sults). One of the discordant hybrids retains $B C L-2, \psi \lambda-1$, and $G R P$ but lacks PEP-A and $M t-1 k b$. Another nondiscordant hybrid, and five of its subclones, lack PEP-A, Mt-l kb, and $G R P$ but retain $B C L-2$ and $\psi \lambda-1$. These results indicate that GRP is located on chromosome 18 between bands $\mathrm{q} 21$ and $\mathrm{q} 23$ and that it is flanked distally by peptidase $\mathrm{A}$ and $M t-1 k b$ and proximally by $B C L-2$ and $\psi \lambda-1$. The other apparent discordancy resulted from differing sensitivities for the detection of $P E P-A$ protein and molecular hybridization; $G R P$ and $\psi \lambda-l$ were both detected very weakly and $P E P-A$ was not detected.

In situ hybridization to human chromosomes using a ${ }^{3} \mathrm{H}$-labeled nick-translated GRP probe was performed to corroborate and further define the map assignment. Figure 2 is a histogram summarizing the positions of 262 autoradiographic grains over specific chromosomal bands in 181 independent chromosome spreads. In this analysis 14 grains $(5.3 \%)$ were located on chromosome 18 at band $\mathrm{q} 21$. This confirms and extends the somatic cell hybrid data presented earlier.

\section{DISCUSSION}

Chromosomal rearrangement of genes encoding growth factors, growth-factor receptors, and oncogenes are frequently observed in tumors and derived cell lines. These rearrangements can change the structure or regulation of adjacent genes, contributing to the altered growth properties of tumor cells. With this in mind, it is of interest to note that chromosome band $18 \mathrm{q} 21$ is the position of a common translocation in B-cell lymphomas $[\mathrm{t}(14 \mathrm{q} 32 ; 18 \mathrm{q} 21)](26,27)$. This translocation is correlated with expression of a $4.0-\mathrm{kb}$ and 6.5-kb mRNA from an adjacent gene, $B C L-2$, which is therefore implicated in B lymphomagenesis or tumor progression $(26,27)$. Both human $G R P$ and $B C L-2$ are localized to the chromosome band $18 \mathrm{q} 21$. Without a more detailed linkage study, the distance between these two loci remains uncertain. Perhaps the 

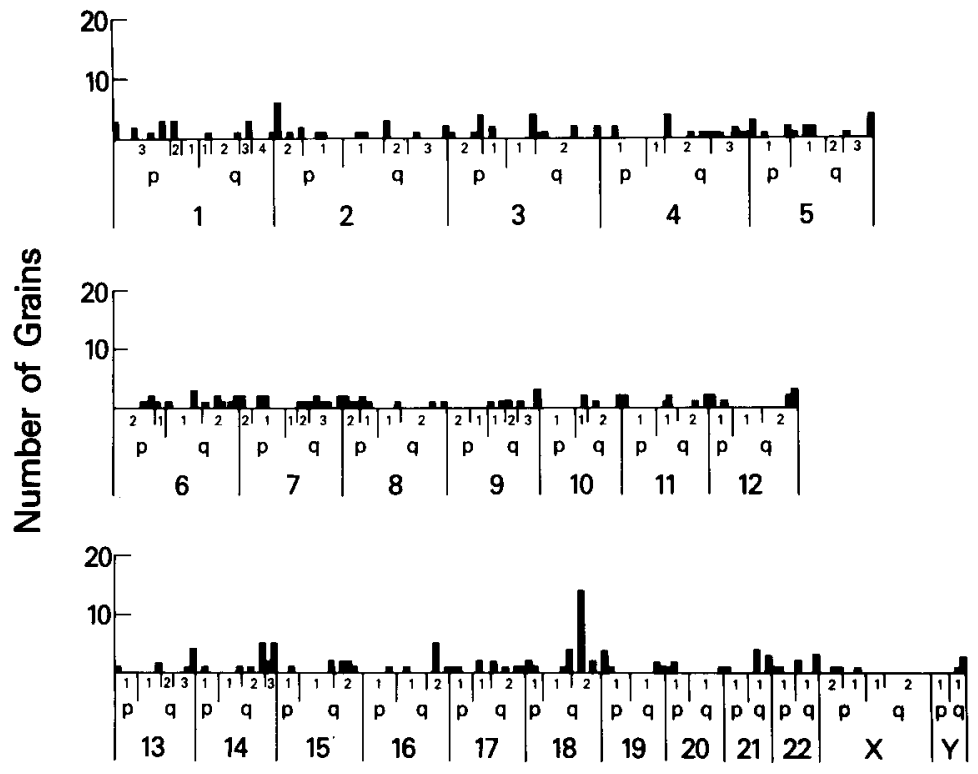

\section{Chromosome Number}

Fig. 2. Histogram of grain distribution from in situ chromosome hybridization of GRP cDNA probe. A ${ }^{3} \mathrm{H}-l a b e l e d$ GRP cDNA plasmid is hybridized to 181 normal male metaphase chromosome spreads, washed, and autoradiographed as described previously [Kirsch et al. (23)]. The data are analyzed by tabulating the positions of grains on chromosomal bands and summarized in a histogram showing the number of grains detected over each band. The total number of grains counted was 262 , and 14 were mapped to $18 \mathrm{q} 21(5.3 \%)$. The statistical significance of the peak at $18 \mathrm{q} 21$ is $P \gg$ 0.05 . Large numbers under the histogram indicate chromosome number, and small numbers show the bands on each chromosome. The letters $\mathrm{p}$ and $\mathrm{q}$ designate two arms of each chromosome.

human GRP gene which encodes a peptide hormone with growth modulating properties in SCLC and Swiss 3 T3 fibroblasts might also be transcriptionally activated by this or other similar rearrangements.

\section{ACKNOWLEDGMENTS}

The authors wish to thank Tanya Myers for her expert help in preparing the manuscript. A.M.L.V. is a permanent Research Associate from the Fonds National de la Recherche Scientifique (Belgium) and partially supported by an EORTC fellowship.

\section{LITERATURE CITED}

1. McDonald, T.J., Jornvall, H., Nilsson, G., Vagne, M., Ghatei, M., Bloom, S.R., and Mutt, V. (1979). Biochem. Biophys. Res. Commun. 90:227-233.
2. Westendorf, J., and Schonbrunn, A. (1983). J. Biol. Chem. 258:7527-7535.

3. Brown, M., Allen, R., Villareal, J., Rivier, J., and Vale W. (1978). Life Sci. 23:2721-2726.

4. Dockray, G.J., Vaillant, C., and Walsh, J.H. (1979). Neuroscience 4:1561-1568.

5. Wharton, J., Polak, J.M., Bloom, S.R., Ghatei, M.A., Solcia, E., Brown, M.R., and Pearse, A.G.E. (1978). Nature 273:769-770.

6. Yang, K., Ulich, T., Taylor, I., Cheng, L., and Lewin, K.J. (1983). Cancer 52:819-823.

7. Tamai, S., Kameya, T., Yamaguchi, K., Yanai, N., Abe, K., Yanaihara, N., Yamazaki, H., and Kageyama, K. (1983). Cancer 52:273-281.

8. Erisman, M.D., Linnoila, R.I., Hernandez, O., Di Augustine, R.P., and Lazarus, L.H. (1982). Proc. Natl. Acad. Sci. U.S.A. 79:2379-2383.

9. Sorenson, G.D., Bloom, S.R., Ghatei, M.A., Del Prete, S.A., Cate, C.C., and Pettengill, O.S. (1982). Regul. Peptides 4:59-66.

10. Wood, S.M., Wood, J.R., Ghatei, M.A., Lee, Y.C., O'Shauneghessy, D., and Bloom, S.R. (1981). J. Clin. Endocrinol. Metab. 53:1310-1312.

11. Weber, S., Zuckerman, J.E., Bostwick, D.G., Bensch, K.G., Sikic, B.I., and Raffin, T.A. (1985). J. Clin. Invest. 75:306-309. 
12. Cuttitta, F., Carney, D.N., Mulshine, J., Moody, T.W., Fedorko, J., Fischler, A., and Minna, J.D. (1985). Nature 316:823-826.

13. Willey, J., Lechner, F., and Harris, C.C. (1984). Exp. Cell Res. 153:245-247.

14. Rozengurt, E., and Sinnett-Smith, J. (1983). Proc. Natl. Acad. Sci. U.S.A. 80:2936-2940.

15. Zachary, I., and Rozengurt, E. (1985). Proc. Natl. Acad. Sci. U.S.A. 82:7616-7620.

16. Spindel, E., Chin, W., Price, J., Rees, L., Besser, G., and Habener, J. (1984). Proc. Natl. Acad. Sci. U.S.A. 81:5699-5703.

17. Sausville, E.A., Lebacq-Verheyden, A.M., Spindel, E., Cuttitta, F., Gazdar, A.F., and Battey, J.F. (1986). J. Biol. Chem. 261:2451-2457.

18. Spindel, E., Zilberberg, U., Habener, J., and Chin, W. (1986). Proc. Natl. Acad. Sci. U.S.A. 83:1923.

19. McBride, O.W., Hieter, P., Hollis, G.F., Swan, D.,
Otey, M.C., and Leder, P. (1982). J. Exp. Med. 155:1480-1490.

20. Naylor, S., Spindel, E., Chin, W., and Sakaguchi, A. (1985). Cytogenet. Cell Genet. 40:711.

21. Polsky, F., Edgell, M., Seidman, J., and Leder, P. (1978). Anal. Biochem. 87:397-407.

22. Harper, M., and Saunders, G. (1981). Chromosoma 83:431-439.

23. Kirsch, I.R., Morton, C.C., Nakahara, K., and Leder, P. (1982). Science 216:301-303.

24. Zabel, B.V., Naylor, S.L., Sakaguchi, A.Y., Bell, G.I., and Shows, T.B. (1983). Proc. Natl. Acad.Sci. U.S.A. 80:6932-6936.

25. McKusick, V. (1986). Medicine 65:1-33.

26. Tsujimoto, Y., Finger, L., Yunis, J., Nowell, P., and Croce, C. (1984). Science 226:1097-1099.

27. Bakhshi, A., Jensen, J., Goldman, P., Wright, J., McBride, W., Epstein, A., and Korsmeyer, S. (1985). Cell 41:899-906. 